\title{
Anthropomastics in Selected Zambian Novels: A Cultural Appraisal
}

\author{
Sylvester Mutunda \\ Department of Literature and Languages, University of Zambia, Lusaka, Zambia
}

Email address:

musvester@yahoo.com

\section{To cite this article:}

Sylvester Mutunda. Anthropomastics in Selected Zambian Novels: A Cultural Appraisal. International Journal of Education, Culture and Society. Vol. 2, No. 4, 2017, pp. 101-113. doi: 10.11648/j.ijecs.20170204.11

Received: May 2, 2017; Accepted: May 17, 2017; Published: July 6, 2017

\begin{abstract}
This paper concerns itself with character names as mediators of theme in Zambian Literary works notably, Bitterness (2005) by Malama Katulwende, Before Dawn (1970) by Andrea Masiye and A Cowrie of Hope (2000) by Binwell Sinyangwe. Given the focus of the present paper, these literary works were selected because they are interesting texts and artworks in different ways. All the personal names in these texts are studied and analysed using the insights from literary onomastics. This paper aims to explore how the character names in the selected fiction serve as devices through which the social reality that the author writes about is encapsulated and analysed, and comprise a fresh way of understanding the novels. The paper concludes that character names in the texts are carefully chosen to serve particular thematic and stylistic purposed.
\end{abstract}

Keywords: Literary Onomastics, Zambian Novels, Bemba, Chewa, Mambwe, Namwanga

\section{Introduction}

The study of names or onomastics has drawn the attention of several scholars including ethnographers, anthropologists and linguists, to name a few. There are two main branches of onomastics known as toponym or topomastics, which is the study of place names; and anthropomastics which concerns itself with the study of personal names. Onomastic researchers have been interested in the study of personal names. Researchers' attention to the study of personal names could be attributed to the significance of personal names in different cultures and society. Notable among research on personal names are studies by Obeng [31], Zawawi [43], Neethling [28], Agyekum [4], Al-Zumor [7], Mutunda [25, 27], Chauke [10] and Olatunji et al. [34]. These studies have shown that, names are not only markers of identity and arbitrary but a source of a variety of information (Agyekum [4]; Suzman [39]).

The use of personal names is equally a very important tool for identifying characters and determining how they are connected to the theme. It is therefore not surprising that anthroponomy has been applied to literary works. This has also been looked at by scholars such as Wamitila [41], Ngonyani [29], Croft [11], and Allagbé [5] to mention just a few. The name given to characters - males or females - in literary text has a suggestive potential based on the message writers intend to convey to readers. Gonzalez [16] notes that, literary onomastics helps in the discovery of meanings which has a contribution to the interpretation of a text. And Wamitila [41] adds his voice to the importance of characters name in literary works when he submits that, character names can be used artistically to achieve a number of goals like encoding a central trait in a particular character's signification, embracing crucial thematic motifs, ideological toning as well as even showing the particular writer's point of view.

It should be pointed out that studies on onomastics in Africa literary texts have so far looked only at canonical writers of West Africa at the expense of lesser known ones. There is therefore the need for further research on literary texts, specifically Zambian novels as representations of different African cultures in order to ascertain the similarities and differences in the naming system of Bembas, Chewas and Mambwe/Namwanga; and the effects of these names on the roles of the characters. It is in view of these issues that this study seeks to undertake a literary onomastics of three selected texts namely, Bitterness (2005) by Malama Katulwende, Before Dawn (1970) by Andrea Masiye, and A Cowrie of Hope (2000) by Binwell Sinyangwe. Given the focus of this paper, these literary works were selected because they are interesting texts and artworks in different ways. 
Drawing on theoretical insights from literary onomastics, this paper seeks to examine Katulwende, Masiye and Sinyangwe's naming or labelling of their characters in relation to the roles and activities they are assigned to in the narrative context in the fictional texts. In short, the paper seeks to answer the following pertinent questions: (1) which sociocultural factors influence the choice of names among the Bemba, Chewa and Mambwe/Namwanga? (2) To what extent do the names of selected characters influence their roles in the three novels? In the next section of the article, I first present the theoretical framework on which this study is anchored, clarifying the concept "onomastics" in relation to such aspect as literature, and reviewing some previous studies relevant to the on-going research topic. In the subsequent section, I carry out the analysis proper, displaying and discussing the findings before concluding.

\section{Theoretical Framework and Literature Review}

This paper employs onomastics as its main theoretical base. Onomastics derives from the Greek word onoma, which means 'name'. By definition, onomastics denotes the name of the persons. The Nigerian scholar, Allagbé [5], quotes Adekoya as saying that a name is an image and a metaphor. It gives not only the identity of a person or an object but it is also a representation of the person or the object. According to Bright, as cited in Allagbé [5], the word onoma is often used to mean a term which can refer to anything or an entity in the physical world. The entity could be a person, an animal, a place, a physical object or an abstract thing.

The Nigerian scholar, Allagbé [5], uses the term "literary onomastics" to mean the study of the semantic import of proper names in literature or in a literary text. He further quotes Anderson as saying that the most researched categories of proper names are personal names and place names. According to Alvarez-Altman [6], literary onomastics is a more specialized literary criticism in which scholars are concerned with the levels of significance of names, in drama, poetry, fiction and folklore. These include names of places, characters, etc., as they relate to theme, structure, and other literary considerations. In short, literary onomastics seeks to investigate the link between characters and the names they bear, as well as their relevance. This will be pivotal to the understanding of how they (names) are attached to the consistency and aesthetic of the literary text.

In all literatures, particularly in Africa, names are considered an important and relevant area for literary analysis. Unlike in the Western culture where name is merely a tag, pointer-out which in itself has next to no meaning [2], in many African societies, personal names are not just arbitrarily concatenated words but rather words that reflect the world-view of the people, this explains why they are not randomly bestowed on people; they are given for specific reasons. For example, certain names are given based on the circumstances surrounding the birth of a child. Mutunda [25] in his study on naming practices among the Lunda of Zambia asserts that, if a child is born during rainy day or at the beginning of rainy season, the child would be named muzowa ("rainy day") or musanvu ("early rainy season"). In addition, if he or she is born soon after the death of any member within the homestead, the child will be named Kamfunti "the one who has come back". This is because such a person is thought to have returned to the homestead where he or she once lived as a family member.

In tandem with Mutunda [25], Guma [17] in his study on the cultural meaning of names among the Basotho of Southern Africa argues that, to name children after events may serve psychological and emotional needs of the society or family. For example, when the birth of a boy coincides with a calamity that has befallen a family, he is named Kotsi (danger or accident), and during an invasion of locusts that have destroyed planted crops the names Tsie (locust), Sehlolo (disaster) may be used for boys. Often people will refer to an event whenever one asks for their dates of birth. Pragmatically, as Guma [17] emphasizes, naming after events serves as a "recording" system. Therefore, individuals embody the meaning associated with their names and in the process try to live up to the expected behaviour or personage that is dedicated to the name. Some individuals go to the extent of asking elders about the chronicle associated with their name and compose poetic recitals around the name.

Furthermore, quoting Mohome (1972), Guma [17] submits that among the Basotho, names are seldom chosen at random and usually recall a grandfather or other important relation. Naming children after their paternal or maternal relatives serves to perpetuate the names of ancestors, and it brings grandparents and grandchildren closer to one another. Alternate generations of grandparents and grandchildren are linked together. It is also believed that the child so-named will inherit the virtues of his grandparents. Religiously, to honour ancestral forces for their influence upon the living, a child is named after one of them.

In the same breath, Omari [35] indicates that among the Ndebele community living in Mpumalanga in South Africa, the name of grandparents (living or dead) are passed from one generation to another by naming children who are born in the family after them. As Omari [35] further states, this practice of naming children after their grandparents has some significance; it is a way of paying respect and remembering the living-dead people who are considered as members of the family. In this way a clan name is perpetuated. Thus, as Fasiku [13] points out, the name, which is inherited from the dead, enters into and emerges with the child at birth and protects it. This view is articulated by Mbiti [23] who acknowledges that the departed are also remembered by naming children after them, especially if their features have been inherited by these children. Therefore, in African societies, the dead or the ancestors are not readily forgotten but are recalled and respected through names. They are considered to be still alive because their great grandchildren will use their names for many years to come.

Moreover, Suzman [39] in her study of Zulu personal 
naming practice states that, the distinction between African and English personal naming practices is largely based on the motivation for naming. Quoting Josiah Tyler (1891), Suzman [39] further notes that, in Zulu tradition, children receive names that reflect values attitudes within a particular social context such as social circumstances connected with children's birth. For instance, "if a small snake happens to be seen or killed when a boy is born he is called Unyokana (A little snake). Should the infant be a large one, he receives the appellation Ungagumuntu (As large as a man)".

In his recent study of the naming practices among the Luvale of North-western Zambia, Mutunda [27] asserts that, the Luvale world view revolves around the belief that the living, the dead and those yet to be born are linked like an unbroken chain. The ancestral spirits known as mahamba are always among the living. Thus, to find out the name that reflects the person the child is already born to be, parents would greet the baby in words and songs using different names; the one that makes the child smile is assumed to be the right one. Sometimes, if it happens that the baby falls sick after bestowing a particular name on him/her, the traditional healer or herbalist - chimbanda - will be called upon to treat the sick child. The herbalist will subsequently select a new name and bestow upon the child, because it is believed that misfortune is connected with the previous name.

This posturing is not specific to southern Africa alone. According to Gerba [15], the Orono have a system of naming babies after paternal or maternal relatives as a way of perpetuating the names of ancestors. Orono people give the names of the ancestors to the new born baby so as to retain their ancestors' name. Furthermore, Gerba [15] observes that, this type of naming can remind the family or the community that a baby is from such and such a clan. It also deters a people to marry from the same clan as they are considered to be near kin to one another. Gerba [15] concludes that, this type of naming can enable one to suggest that name givers give children names that emanate from the social fabric of their lives.

Finnegan [14] argues that, in some African communities, names can be used to express ideas, aspirations, sorrows, or philosophical comments. Giving the example of the Ovimbundu of Angola, she argues that, an Ovimbundu mother can lament the loss of a child in a more complex form of a name representing an abridged proverb such as 'They borrow a basket and a sieve; a face you do not borrow'. The implication is that, though she may have other children, they will never have the same face as the one that she has lost.

In his work African Religion and Philosophy, Mbiti [23] observes that, in some African societies, the birth of twins or triplets in considered a curse, an event out of the ordinary that should be treated with feared or care; while in others, such birth is considered a blessing that should be treated with joy. Citing the example of Central Africa, Mbiti [23] avers that the birth of twins or triplets is a sign of fertility; hence it is greeted with joy and satisfaction. Furthermore, children of such births are believed to have special powers; they are known as Tilo "children of God and heaven". Thus, for instance, when a village is threaten with calamities such as drought, flood or locusts, people turn to twins or triplets to pray on behalf of their community.

In his study of naming customs of the Mbeere people of Kenya, Katakami [18] observes that, the basic principle of naming among the Mbeere is to name the new-born after another person, mainly grandparents. This principle is related to the fact that persons in the same and alternate generationsets are regarded as being in the same category. However, successive deaths of babies often cause the parents to give up naming the latest baby after a person. Instead they name a baby after things that have little importance, such as mati (leaves), macaki (grass), and kanigo (faeces). They sometimes decide to call a baby 'nameless' (Iriga). This arises from the parents' worries over yet another death. A death within the homestead may also affect naming. Parents sometimes name a baby Nduma (darkness) if he is born soon after the death of any member within the homestead, who dies when the moon is under the horizon at sunset.

According to Obeng [31], among the Akan people of Ghana, names are a representation of the Akan culture, thought, philosophy and religious beliefs. In his study of Akan death- prevention names, Obeng [31] notes that, if a couple has lost many of their children at birth or thereafter, they may give a child a "death-prevention" name". Deathprevention- names, Obeng [31] further submits, have the ability to assure survival of the child bearer.

The Ibibio people of South-eastern Nigeria also practice death-prevention naming known as Ésén émà (strange birth). According to Mensah and Offong [24], the Ibibio give deathprevention names to children who undergo cycles of death and rebirth within the same family). Such children are usually given disgraceful names that portray them to underworld spirit as worthless and unwanted by the biological parents or name givers. In this regard, the name is believed to hide the identity of the name bearer from harmful influences of the underworld forces. These spiritual forces are believed to control the destiny of the reincarnated child, including his right to live. The adoption of death prevention names is therefore, a psychological strategy to deceive the spiritual forces, in order to deter them from harming the fragile children and allow them to live.

In his study of Ghanaian personal names, Adjah [3] indicates that, Ewe, Akan, and Ga children are named according to the day on which they are born. This is considered their soul name. Every day of the week is believed to be under the protection of a god and each day has a set of names for males and females. As soon as a child is born, he or she acquires the name that corresponds with the day of birth. Adjah [3] concludes that a name assigned is considered as part of one's destiny; it is a child soul, and the child's behaviour and fate are both affected by the day of birth.

Furthermore, Ogie [32] in his study of Edo personal names and worldview revels that, for the Edo of Nigeria, the names given to a child distinguishes the infant socially and incorporates it fully into the wider society. The Edo naming 
ceremony takes place seven days after birth for healthy children and fourteen days for sickly ones. The naming ceremony not only separates the infant from the spirit world, but also initiates him into the physical world of human existence. This is attributed to the fact that the naming of a child is seen as the uniting of an individual with the universe and society. A sickly child is watched by the parents for fourteen days. During this period, a temporary reference such as Umweni which means 'you do not have a name' might be given to the child. If the child is ill for a long time, the name might be adopted. A sickly child that recovers after the stipulated period is then given an identity and incorporated into society through the naming ceremony. This is because once a child is named, he / she is believed to desire life.

In addition, Udoye and Cyril [40] in their study of the morphological analysis of Akwa personal names reveal that, most of Akwa personal names have God as their semantic base. Structurally, there are names with God in the initial as well as the final position of sentences. However, in a nominal compound, God occurs as a second noun and in the case of a verb and a noun where a verb is an imperative verb, the noun represents God.

In another study of praise names of Igbo chiefs, Oha [33] argues that chiefs' praise names are not only a sign of identity but also ideological in nature. In that, the praise names which are used by chiefs reflect their social relationship, power relations, and reconstruct their goals. In the end, it helps to reconstruct identities of acceptable, desirable, and respectable images for their bearers. These names relate to the philosophical and cognitive experiences.

The above studies suggest that in Africa, names are not arbitrary but they are based on socio-cultural and ethnopragmatic contexts. In other words, names are not just given; name givers consider the surrounding circumstances before naming a referent. As far as the use of names in literary text is concerned, Wamitila [41] in his study submits that names of characters are very important in literature. The characters' names go beyond the confine of being seen as a mere tag that distinguish one character from another to being a semantic, pragmatic, allusive, and symbolic import that must be seen in the perspective of the overall structure of a particular work. He further adds that character names can be used as expressions of experience, ethos, teleology, values, ideology, culture and attitudes of varying shades [41]. Indeed, as Ennin and Nkansah [12] contend, names play a significant role in the narrative and lend a special aesthetic quality to the story; they foreground particular themes or motifs, reveal the fictional character, situate a character within a specific and identifiable cultural setting, reveal different point of view and even used as a plot device, as a sarcastic or a satirical strategy. It should be noted that, writers of literary texts have the tendency to use allegorical names that reflect the important traits of a character either humorously or ironically. In addition, Ngonyani [29] quotes Ashley as saying that in all literature names perform different functions such as telegraphing allegories, clarifying characters or places, and bearing the idea of the authors. In this respect, I agree with Alvarez-Altman [6] when she posits that just collecting and listing names for a work of literature is not enough and not realistic. There need to be other considerations, so as to make the literary name relevant to the work.

This view is articulated by Debra King [20] who, in her investigation of names in African-American literature acknowledges that, names serve not only to communicate to the reader the characteristics of the referent or to personify behaviour, but also to convey the narrator's or writer's message (Cited in Ngonyani [29]). Indeed, once personal names are deployed in literature, their function is no longer indexical or deictic but rather specific (Allagbé [5]). Therefore, decoding of the names becomes an important critical engagement that helps the reader to decipher the text in which the names are found. In short, an investigation of the meaning of names and their relevance will contribute to the grasp of how they add the texture to the texts; in the process, one learns to appreciate and enjoy the stories and thus enriches his reading experience.

In his study titled The power and politics of naming, Butler [9] contends that, there are three onomastic techniques that contribute to the distinctive nature of dystopian fiction namely propaganda, classification, and regulation. The propaganda technique deals with the fact that names are shaped according to the naming authority, while classification deals with the fact that there is a direct link between form and intention of use. As for regulation, it deals with the fact that literary names are selected intentionally to direct character interpretation.

It is clear from the foregoing that there is a dialectical relationship between a writer's naming and his/her ideological orientation. According to Allabé [5], ideology means a set of beliefs, attitudes, biases and perspectives the writer cogently holds onto and by which s/he interacts with his/her readers. I therefore maintain that decoding the names becomes an important critical exercise in as far as it helps the reader in his deciphering of the text in which the names appear.

The above literature point to the fact that, names in literary works go beyond just the concept of address term to other factors that are likely to affect the overall interpretation of a literary work. Thus, this study looks at the names in three Zambian novels namely, Bitterness (2005) by Malama Katulwende, Cowrie of Hope (2000) by Binwell Sinyangwe and Before Dawn (1970) by Andrea Masiye; and the effects of the names on the roles of characters in these texts.

\section{Character Analysis and Discussion}

Bitterness is a novel that describes the incompatibility of old Zambian traditions and modern life. The narrative focuses on the teen age protagonist Besa Musunga, who travels from Samfya, his native village, to the capital city Lusaka to pursue his educational dreams at the University of Zambia. As required by tradition, Being the only person to attain higher level of education, his family and indeed the 
entire clan look up to him for material assistance once he completes his education and returns home to get married to a woman his family had chosen for him and eventually settles in his native homeland. Unfortunately, Besa only manages to get a teaching job for which he is not even paid. He barely sustains himself and cannot meet the expectations of his family. When he travels to the village for his mother's funeral, he carries nothing except the knowledge in his head. $\mathrm{He}$ also rejects his parents' choice of bride. Besa is then forced to re-examine his feelings towards family, tradition and his country. In this novel Katulwende deals with themes such as disillusionment in post-independent Africa, tradition and culture.

The Bemba names identified in Bitterness are affected by association with clan or totem, ancestral spirits, and sociocultural circumstances. The Bemba people function within social structure that delineates social groupings which identify relationships and roles between groups and individuals. These groupings are called totems (imikowa), and each totem has a name (Penda [37]). Bemba totems usually belong to the animal and vegetable world, real things. To identify with and maintain the association with their individual totems, a number of people use their totem as personal names. These names are based on the thirteen clans of the Bemba people. Examples of totemic names identified in Bitterness include Besa of the millet or nshima clan and Mumba associated with clay/loquart clan.

In addition to totemic names, theophoric names are also given in Bitterness. These are names that depict the Bemba's belief in the supernatural beings and their power. As Penda [37] aptly points out, like most African cultures, the Bemba believe that Children are the reincarnation of human spirits from the world of the dead and, as such, ancestors have more authority than human beings in naming a child. Whereas crying or becoming sick is a baby's way of rejecting the ancestral spirit that comes with the name, smiling, sneezing, or kicking legs in happiness is interpreted as the acceptance of the spirit name by the child. Thus, in Bitterness, we have a name such as Chanda, Besa's mother.

The Bemba people often name their children depending on socio-cultural circumstances or events surrounding the birth of the child. There are a variety of circumstances that can determine the name of an individual in the Bemba setting. These circumstances can relate to anthroponomy (place of birth of the child), temporynms (the period of birth) and manner of birth. In the novel, one name is identified as circumstantial name and another one as reflecting manner of birth; these include Washama and chola respectively. Washama derives from the verb -shama, signifying you are unlucky or unfortunate, and Chola is a name given to the child born immediately after twins or a third child among triplets.

Besides these general interpretations of names in the Bemba setting, the novel also contains certain names that have implication for characterization. Besa Musunga is the Protagonist in Bitterness. Literary, his names means 'keeper/custodian' of the millet/nshima clan. As the protagonist father rightly explains the moment he takes Besa to their ancestral shrine:

My son, I leave you this load to carry, for my time in this earth has ended. It might be today, or tomorrow, when I shall be reclaimed by the soil. [But] I want you to hear this. [...] You were named "Musunga", because your work shall be to hold things together in harmony. You are one who holds. Starting from first recollection of our social memories, our fathers say that this shrine and many others have meant a lot to our people. Spread the teaching of our ancestors, or else the tribe will drown. And, my son, slave for your people as you saw me do. The survival of our people rests in the things that are ours, in the works and thoughts that are cultivates here. You should harden your strength and endurance. [...] You shall fulfil your works according to the oracle of chipepa. [19]

The name Besa Musunga is, therefore significant as far as his role in the story is concerned. Given the fact that Besa is the only son and first born of the family, his father, Musunga Fyonse, expects him to grow up in the ways and thinking of the tribe; most importantly, to uphold tradition and ensure the sustainability of his clan and tribe. He is also the only one to have attained a higher level of education in his family. On one hand, prior to Besa Musunga's departure for the University in Lusaka, his parents and indeed the entire clan were sad that their son might not grow in the tradition way as they would wish. On the other hand, they were delighted that upon completion, the young man, as he is name states, will be able to take care of the material needs of his clan and return home to get married to the bride that was chosen for him. However, when he graduates, he is unable to raise them to the standard of living they had expected for; he only manages to land a job for which he is not even paid. When he returns to his native homestead for the funeral of his mother, he carries nothing except the knowledge in his head. He thus becomes incapable of occasioning change in his universe.

Furthermore, Besa Musunga breaks instead of keeping his tradition and culture, by not marrying the woman that his parents had chosen for him. After the funeral, the family gathered to discuss Besa Musunga's marriage, his uncle explains:

Besa, [you] have grown - [you] needs a woman to leave with [now that] you have completed [your] studies. Your mother said, "I want Besa to marry into the house of Mulonda." After thinking about it, [the family has] decided that, of all the three daughters Mulonda has, Chama was the best choice. She is a virgin, she is cultured, and she is generous. [19]

But Besa Musunga defies his family wish and rejects that choice. No matter how much he allowed himself to be persuaded by his family and relatives, Besa could never abandon Shantiee for another woman. He is so attached to her that he cannot imagine his life without Shantiee, a mixt race woman he has met at the University: "Her heart was his heart, her heart was his cult" [19]. Responding to his family's choice, Besa respectfully said:

Uncle, I thank you for choosing this woman for me. I 
thank you very much for the trouble you took on your shoulders. On the other hand, don't you want me to marry the woman I love? [...] Why can't I marry a woman of my choice [...] I appreciate your wishes uncle, but I have my reasons too. Besides, I don't love Chama. I love the woman you have rejected as a clan. [...] Uncle, someone's tribe and cultural roots are not as important as someone's heart. Shantiee is a wonderful woman and you have no reason not to want her. You don't the facts - you are judging her unjustly. [19]

By failing to take care of the material needs of his clan, and defying his clan's choice of bride, Besa is alienated from his relatives. In the end, he becomes an ineffective god, incapable of occasioning change in his universe. For this reason, therefore, his father curses him: "now I know, my son, that you have betrayed this land, this Ng'umbo country, for which I am cursing you, you traitor of my own blood" [19].

Besa's father, Musunga Fyonse, whose name signifies custodian/keeper of everything including the ancestral shrine, is presented by Malama Katulwende as an embodiment of tradition; he represents the gods and beliefs of the entire clan. As custodian of the ancestral shrine, his duties include making sacrifices, offerings and prayers, conducting rites and ceremonies, giving advices, caring for the shrine, and above all, acting as an intermediary between the spiritual world of the ancestors and his community. Ironically, the arrival of Christian missionaries, whose mission was chiefly the evangelisation of Africans, brought about a cultural vacuum as many traditions where abandoned, forgotten or replaced. Thus, ever since his wife Mumba Chanda converted to Catholicism - the White man's religion, she abandoned her ancestral religion, and "started to speak badly of [her] shrines. She believed in the magic of the stranger. [...] She stood against everything [her husband Musunga Fyonse] believed in" [19]. In one instance, she implores him to abandon his beliefs stating: "Musunga, Yesu Klistu is calling out to you to be saved. Stop worshiping your shrines and your relics and return to Yesu. In Him alone will you find peace. You're a troubled man. Give yourself up to Him and all your troubles will leave" [19]. But, being custodian and representative of the ancestral gods and beliefs of the entire clan, Musunga Fyonse is not ready to abandon the ways and thinking of the tribe no matter the circumstances. This is the reason why he often takes his son Besa to the ancestral shrines so that he can acquaint himself with traditional beliefs which he is expected to keep and uphold once his father is long gone.

Table 1. Names in Bitterness.

\begin{tabular}{|c|c|c|}
\hline Characters Name & Meaning & Role \\
\hline Besa Musunga & $\begin{array}{l}\text { Of 'millet'or 'nshima' clan } \\
\text { Keeper/Custodian }\end{array}$ & $\begin{array}{l}\text { Protagonist. Son of Musunga and Chanda. He is expected to uphold tradition and } \\
\text { ensure the sustainability of his clan and tribe. But, despite being a University graduate, } \\
\text { Besa Musunga gets a job for which he is paid nothing; hence, he fails to care for his } \\
\text { family and clan. Besa also defies tradition by marrying a woman who his neither his } \\
\text { parents'choice nor belong to his clan. For that, he is cursed by his father. }\end{array}$ \\
\hline Musunga Fyonse & $\begin{array}{l}\text { Keeper/Custodian of everything including } \\
\text { the ancestral shrine. }\end{array}$ & $\begin{array}{l}\text { The protagonist's father. He embodies tradition; represents the gods and beliefs of the } \\
\text { entire clan. However, due to the encroaching Christian religion, he fails to keep and } \\
\text { maintain his traditional faith and beliefs. }\end{array}$ \\
\hline Mumba Chanda & $\begin{array}{l}\text { Name associated with clay/loquart clan. } \\
\text { Ancestral spirit }\end{array}$ & $\begin{array}{l}\text { The protagonist's mother. } \\
\text { After her conversion to the European colonizer's religion (Christianity), she begins to } \\
\text { question her own traditional beliefs and culture. }\end{array}$ \\
\hline Chola & $\begin{array}{l}\text { Child born immediately after twins or } \\
\text { third among triplets. }\end{array}$ & Besa's Aunt \\
\hline Washama & $\begin{array}{l}\text { From the verb - shama meaning 'unlucky } \\
\text { or unfortunate' }\end{array}$ & Besa's best friend. He is very supportive both morally and financially. \\
\hline
\end{tabular}

Binwell Sinyangwe's A Cowrie of Hope is set in two geographical areas: Mbala and Lusaka. The novel tells the story of a young widowed village woman Nasula, who is desperate to search for money for her daughter's secondary schooling. But Nasula is unable to pay for her daughter Sula's education due to economic hardships. Her inability to support her child's education seems to extinguish her hope. However, a friend, Nalukwi advises her to take her last and only bag of beans to Lusaka - the capital city - for sell, where the much sought-after Mbala beans sell lucratively. Nasula takes off for Lusaka, but in the city, she finds herself exposed to new, and predatory dangers: the theft of her beans - on which her hopes depend and which she retrieves after overcoming a series of tribulations.

Among the names found in Cowrie of Hope, there are names whose meanings record the circumstances surrounding the baby's birth, particularly those that describe human qualities; while others are proverbial names, teknonyms and nicknames. Circumstantial names may relate to the place of birth, events taking place at birth time, the weather description at birth time or human attributes; an example of which is Sula, the protagonist's daughter. As for proverbial names, they are those couched in forms of innuendos to portray situations that occurred before, during or after childbirth. Teknonyms are titles taken by parents on the birth of their first child; two such names found in the novel are Nasula, the protagonist, and Nalukwi her best and valuable friend. Other type of names present in this text are nicknames, which are unofficially assigned personal names. In other words, as defined in Oxford Advanced Learners' Dictionary [36], a nickname is an unofficial [...] name for a person that is connected with their real name, their personality or with something they have done. Thus, in $A$ Cowrie of Hope, we learn for instance that when Nasula was 
a baby, her mother nicknamed her Pantoka because she was in the habit of kicking her legs about [38]. We are given another nickname, Namukokolo meaning "one that would rise high" [38]. Hence I can affirm that as all African names, nicknames do not only refer, but also convey a great deal of information.

The name Sula, as explained in Chanda Penda's [37] The Encyclopaedia of Zambian Names signifies to disregard or forget a wrong that has been committed against oneself or others. Sula's name also signifies "let things be". Sula is an obedient and helpful daughter who emotionally supports her mother in her hard times. In one instance, when her mother tells Sula about the unsuccessful trip to her late husband's family to request for her school fees, Sula did not regret but simply sympathetically says: "Don't worry [mother], it's all right [...] I will not be the first or the last person to stop schooling because of lack of money [...] we must accept what is happening to us. It won't help even if we complain and grieve. Who will listen to us?" [38]. Sula is also a girl who takes education seriously, because she believes that only schooling will save her mother and herself from their poverty: "Sula was a blessing [...] She took her schooling seriously and had refused to be weighed down by the severity of their poverty or the reality that she had no father, and that she was a girl, not a boy" [38] the narrator explains.

Sula is very understanding. As her name states, Sula has no nagging demands and does not complain, like other school going children who demand new clothes and nice food. Whenever she is mocked by her peers for bringing poor quality food, she disregards those provocations and teasing and does not report them to the teachers, even her mother; she does not feel offended or take revenge either, as we are told:

Like other children in Swilini and the surrounding villages, Sula, from the first day, never complained about what she wore or took to school. She had never demanded anything. When something was needed at school or the teachers told the pupils to ask their parents for it, Sula would not do so. [...] Nor had she ever threatened not to go to school or stop schooling if such or such happened or didn't happen. [...] Sula's school bag was a gaudy affair made of old, different coloured materials which Nasula had sewn together in desperation and it was the source of much laughter and scorn. But Sula carried the bag with amazing confidence and pride and in patch ridden, threadbare clothes without shoes on her fit. [However], the laughter, jokes, teasing and other aggressive group behaviour fell on death ears and never made the girl cry or become angry as would have been expected. [38].

It is clear from the above quote that Sula's human attitude is a reflection of her name. Indeed, despite all the mockeries, Sula is a determined, courageous and intelligent young girl who never misses classes or forced into fighting. She remains resolute and focused. The narrator is right to say of her that: "The child was a cowrie of hope. A great gift from the gods to one who was so poor and lowly to wear around one's neck for inspiration, and, above all, hope" [38]. I can also add that, despite her abject poverty, Sula dreams big, knowing that only schooling would weed them out of poverty. I can therefore confidently say that considering Sula's personality traits, Nasula was right to nickname her daughter "namukokolo - meaning one that would rise high" [38].

Teknonyms are also used in A Cowrie of Hope. It seems necessary at this point to explain the concept of Teknonym because of its constant use in this study. Teknonym can be described as a special category of names of the construct characterized by the combination of father or mother plus the personal name of a child (Father/Mother + Personal Name of Child). Some examples found in the novel include $\mathrm{Na}$-Sula (mother of Sula), the protagonist and Sula's mother, and $\mathrm{Na}$ Lukwi (mother of Lukwi), Nasula's friend. Mutunda's [25] study highlights the use of Teknonyms in among the Lunda of Zambia, a custom that is also practiced by other Zambian ethnic communities such as the Namwanga/Mambwe. He observes that this kind of address, beside the respect value it holds, it helps the couple to be identified publicly in terms of the child they share. It also put the husband and wife on an equal level as they are addressed as the father or mother of so and so, respectively.

It should be noted that, though teknonymous address is primarily used by spouses among themselves, it is also extended to non-kin members. For instance, among the Mambwe/Namwanga, a young man will address his father's friend as Na-Mwiza "mother of Mwiza". This can be explained by the fact that the Mambwe/Namwanga believe that the respect and obedience given to one's parents or senior kin should be extended to non-kin members. It is also worth mentioning that teknonyms are by no means substitutes for birth names, which one is given at birth. They are rather names that a man or woman may acquire during a life time beside the given name.

Nicknames are also found in A Cowrie of Hope. These names, as Kahari (1990) cited in Mashiri [21] observes, are usually descriptive, summing up the individual's character, physical shapes and idiosyncrasies; a case in point is the protagonist Nasula, whose nickname is Pantoka signifying "kicking one's legs", as she explains: "my grand-mother gave it to me at birth. She said she thought of it because I was born a baby that was in the habit of kicking my legs about" [38]. Some medical scholars claim that when a child is constantly kicking her legs that tells parents that the child needs something or she is just having a swell time [42]. However, the cultural interpretation is that such a child would in future be stubborn or persistent and determined in the face of obstacles.

Indeed throughout the story, Nasula struggles to survive without her parents nor her husband. At an early adult age, she is married out to where she never knew would be the beginning of her problems. This is because her husband always insults her, reminding her of her poor and backward background. Unfortunately, the same husband dies, living her with a daughter to care for. After her husband's demise, as per custom requirements, Nasula has to be inherited by her late husband's brother, Isaki Chiswebe. 
It should be mentioned that widow inheritance is an aspect of African family custom. Under this practice, when a man dies his wife will be inherited one of his brother. The widow then becomes the legal wife of the man inheriting her. The widow can raise children through her new husband. All the children the widow already has become the bonafide property of the dead man's brother who inherits her. Although the practice has been criticized for making women properties of men, Mutunda [26] is of the view that widow inheritance or levirate marriage was initially intended as a support system to provide domestic, economic, moral, and marital support to women and to orphaned children who needed to be kept in the family and be taken care of.

However, Nasula chooses to remain single. She refuses to accept her brother-in-law Isaki Chiswebe to replace his brother in accordance with the Mambwe traditions: "she knew Isaki and his things of the flesh very well [meaning a womanizer]. She also knew the Chiswebe family too well to remain married to one of its members. She refused to be married to Isaki" [38]. By refusing to adhere to the patriarchal tradition of wife inheritance, Nasula asserts her own individuality and personal worth. She is able to see the consequences of such a marriage - especially that Isaki was a womanizer - and cannot accept to be objectified. Nasula is clearly expressing her disapproval of the tradition of widow inheritance. She also criticizes the notion that women are property that can change hands.

For refusing to adhere to tradition, her in-laws grab all the property the late husband Winelo Chiswebe left her and her daughter, with the intention to make Nasula suffer. However, the protagonist is not moved; instead, she is bold and determined to struggle for her and her daughter to survive.
Indeed, "Nasula, she who was supposed to be the mother of 'let things be' would not let things be over her daughter's schooling" [38]. She wants to educate her only daughter by any means possible, for she sees education as the key to success if her daughter is not to toe her own line of suffering: "you must go to school. You can't stop your schooling just like that $[\ldots]$. Do you not see how we are suffering because I did not go to school? You want your future to be like this?" [38], she tells her daughter Sula. Thus, following the advice of her friend Nalukwi, Nasula decides to take her last bag of beans to Lusaka for sale, so as to educate her daughter. The motivation, zeal and perseverance to educate her daughter come from observing other women who are educated and whom she has seen how they have succeeded in life and now stand on their own.

However, Nasula's hope dashes when a conman named Gode Silavwe, robs her and escapes without paying for the bag of beans, which was the only last hope for her to educate her daughter. This is what she has to say after Gode Silavwe dupes her bag of beans: "I don't want to leave the place which owed the death of my daughter's future" [38].

The above quotation shows a heart full of determination. Nasula struggles, searching for Gode in the entire market for six days with little food and without any care for her looks. She knows that finding Gode and the bag of beans is the only source of survival for her and her daughter. Through the help of Samson Luhila, the commanding police officer, Nasula receives double the amount for the bag of beans. After all the ordeals and tribulations, Nasula is finally relieved; her hope has been realised, she will now be able to send her daughter to school.

Table 2. Names in A Cowrie of Hope.

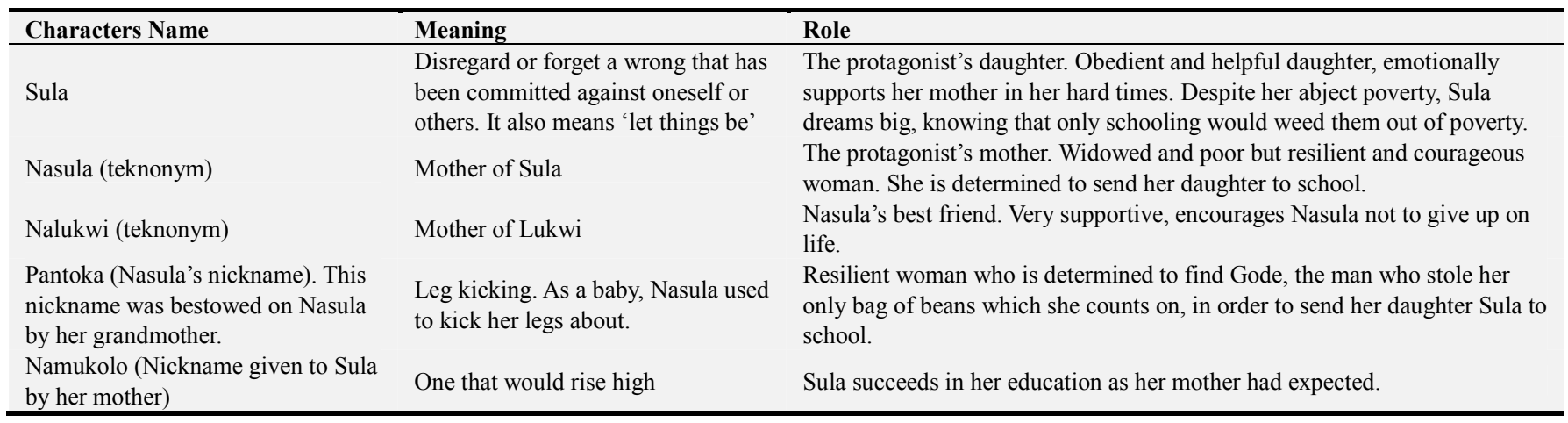

Andrea Masiye's Before Dawn is set in a small village in the Chiparamba valley of Eastern part of Zambia. In this novel, Masiye documents the customs of the Chewa people, but centres his story on one character, Kavumba, son of Menyani Banda and Tinenenji. When his mother died of a septic ulcer, the young boy is left to fend for himself as his father deserts him too. Thus, Kavumba goes to work for the Bwalo or village council, and for the menial work he does, he is rewarded with leftovers because of scarcity of food. This marks the beginning of his ordeal.

Chewa names in the text are affected by social aspects of the family, hopes, traditional beliefs and wishes for the child, circumstances surrounding the birth of the child. Others are proverbial names. These are names that have been sourced from proverbs and other forms of oral literature, such as poems, riddles, songs and so forth. They are accepted as shortened yet valid substitutes of the proverbs to which they correspond while managing to convey the entire meaning of those proverbs. These names serve the same basic functions as proverbs themselves, such as stressing gratitude, generosity, solidarity, social cohesion and so forth (Finnegan [14]). In addition, these names are couched in forms of 
innuendoes to portray a situation that occurs before, during and after pregnancy [27]. Examples of such names are Menyani Banda's wife Tinenenji meaning (what can we say) and Ganizo (thought) the Bwalo (men's meeting place) keeper, Dingani ('to be alone' i.e. baby whose parents are expressing the sentiment that too many elders in the extended family have died), and Thandiwe (beloved).

In addition to proverbial names, other names found in Masiye's Before Dawn reflect hopes, traditional beliefs and wishes for the child. Menyani is the son of Banda, the village Headman. Literary, his name means a child who is expected to beat/excel in diligence, hard work, leadership, competitive activities [37]. Thus, being the Headman's son, Menyani is expected to be the heir of his father's throne. Banda the father wants to prepare the son in leadership skill by ensuring that Menyani frequently visits the men's meeting place (Bwalo), were he can acquire wisdom and learn from elders the Chewa traditional way of life. Conversely, Menyani seldom visits the Bwalo and remains confined to his compound with his wives. Thus his father advises him: "Leave your wives alone, you will learn nothing from them. Stay at the Bwalo, listen to the wisdom of your elders; understand the affairs of the people. That way you become a good leader" [22].

Despite his father's advice, Menyani remains defiant. This explains why he is dubbed "solitary hunting hyena". In one instance, Headman Banda summons Menyani to the Bwalo to explain his failure to report - as required by tradition - the birth of his child to the keeper of the Bwalo. Menyani's arrival at the Bwalo attracted comments from elders, and Headman Banda said to his son: "you're almost a stranger here at the Bwalo, Menyani. That's why people call you lone hunter" [22]. For his disregard of tradition and omission of his duty, Menyani has to be fined: "Custom demanded that [he] kill a goat and give the head and one hind-leg to the Bwalo-keeper" [22]. And the Bwalo-keeper said summarily: "Menyani must not be allowed to ignore our ways of living. As the son of our Headman, he should be a good example to others. Otherwise, the village will break up" [22]

But, Menyani continues with his defiance. Unhappy with the decision of the Bwalo, he promises to beat up Ganizo the Bwalo-keeper: "I will see you Ganizo, one of these days" [22]. A fight ensues; but Ganizo is still determined to make Menyani obey the customary rules: "I am Ganizo. I'll teach him to obey the rules of our village" [22], he says. The irony of the situation is that, Menyani's behaviour does not meet the expectation of his parents. Going by his name, Menyani was expected to beat in leadership. On the contrary, he beats anyone who opposes his will.

In another instance, while at his compound, Menyani saw a fleeing woman crush through the gate of his enclosure; it was Namkugunwi - the midwife - followed by her husband Ganizo, who wowed to beat her for having helped the wife of the ungrateful Menyani deliver: "Ganizo had blamed the Namkungwi for helping wives whose husbands were wrecking the life of the village" [22]. But Menyani thought Ganizo had come to fight him, a brow then ensued. When the incident was reported to the elders' council, Menyani was fined, he had to pay a goat and two white hens to the Namkungwi (midwife). But, once again Menyani broke the traditional code saying that he would not obey the councillors' ruling.

Menyani's behaviour is reminiscent of Okonkwo, the protagonist in Achebe's [1] Things Fall Apart. Like Okonkwo, Menyani sets out to show his animus - the male soul image - and obliterate any inclinations of anima that is, in his view, associated with his father and the entire village eldership. Menyani thus sets value of physical strength. For this, he is rejected by the community that considers him a stranger. Menyani's nature is such that he needs to subject everything to his will. What he cannot subject to his will he rejects. Herein the root of his alienation.

Besides proverbial names and those that reflect the hope, belief, and expectation for the child, Masiye's novel also contains circumstantial names that have implications for the characterization. These names are given to children based on the circumstances surrounding the child's birth from his/her pre-natal to postnatal as well as that of his/her family situation/condition. Commenting on circumstantial names, Blum [8] contains that these names are viewed as governing the child's fate in some ways; they should harmonize with the time and often place of birth. Kavumba is the protagonist in Before Dawn. Literary, his name means, as the protagonist explains: "I was named Kavumba - the whirlwind - because my mother had eloquently complained about my sex" [22]. Besides, prior to Kavumba's birth, while his mother was in labour pains, a frightening flash streaked across the firmament and a booming thunder echoes in the distance.

The name Kavumba (whirlwind) also has a particular religious significance to the villagers. As the protagonistnarrator explains: "[...] the cyclone was a significant centre of my people's beliefs. This natural phenomenon appeared to account for almost every occurrence in our village" [22]. For example, it is believed that in one of the hills that surround the village, lives a sacred serpent (Thunga) who brings life and death [22]. According to Adekoya "A name is an image and a metaphor. It not only gives the identity of a person or an object but it is also a representation of the person or the object" (Cited in [5]). Thus, each time a whirlwind sweeps through the Chiparamba village, it is a manifestation of the serpent returning to his abode from a visit to villages that had incurred its displeasure. In such an instance, spirits have to be worshipped and sacrifices offered, to prevent the anger of the serpent whirlwind from destroying the village.

Following his mother's death and the subsequent living of his father to the mining city in search of a job, Kavumba remains helpless. In order to survive, the orphan Kavumba resorts to performing some menial jobs at the Bwalo including running the errant, acting as a the village carrier to inform the people of the arrival of the European TaxCollector; in return he is rewarded leftovers because of the scarcity of food.

Kavumba subsequently leaves the village for the city to "see the bright lights of the towns" (88), thinking that "[He] 
would use [his] hard-earned [elementary academic education to] find employment there, buy beautiful clothes and return to the village. [He] would show them the value of education" [22].

Once he arrives in the Lusaka, he first goes to Kaligo's home in Mazabuka town, where he expects to be accorded a warm welcome, since they (Kavumba and Kaligo) both come from the same village and have not seen each other for a long time. But, soon Kavumba realises that Kaligo's wife is unwelcoming and that, "[he] would have difficulty in finding a prestigious employment which would commensurate with [his] newly acquired education" [22]. Like a whirlwind, Kavumba's life spins around, making him leave Mazabuka for the capital city Lusaka, where he finds a job at $\mathrm{Mr}$. McDonald's house as babysitter. However, Kavumba fails to stand the knotty behaviour of Mr. McDonald's son, forcing him to leave his employment. Later, Kavumba applied for a clerk job at the Lusaka District Commissioner's office. Unfortunately, he failed to get the job because his level of education was not sufficient for a clerk job. He thus miserably retired to Kabwata Township, where he was hosted by Mwale, another village mate. Later in the novel, the reader learns of a police raid that is intended to arrest loafers. Mwale then advises Kavumba to run away and hide at some safe place in the surrounding bush.

Shortly after the police raid, with the help of his host, Mwale, Kavumba finds work as gardener at Mr. Marais' house. But, he is fire shortly thereafter because he damaged the flowers after smearing them with an unspecified native concoction. Unable to settle in the city, Kavumba eventually returns to his village, determined to start anew and make his life a success. This reminds us of the early mentioned sacred serpent (Thunga) returning to his abode from a visit to villages that had offended him. Kavumba did not take long to readjust to "the world of roots, wild roots and herbs and other medicinal plants which governed the village life" [22].

Title names are also given in Before Dawn. According to Ennin and Nkansah [12], these names were previously used as titles but with times, they have gained the status of a given name. I should add that these names often derive from the occupation or work that one performs. Namkungwi (midwife) is an example of a title name which is significant as far as her role in the story is concerned, given the fact she is presented by Andrea Masiye as the embodiment of Chewa tradition. She is the only midwife whom Menyani runs to when his wife is a labour pains. She is also the one who insists on the right traditional process to be undertaken after Tinenenji gives birth to Kavumba. Thus, after Kavumba's birth, the Namkungwi sprinkles medicine over the baby and his parents: "you are now clean, speak to each other, here is your child" [22], says the Namkungwi as she delivers the baby into Tinenenji's arms.

Besides her midwifery role, Naphiri, the Namkungwi, is also the village medicine woman and priestess. She conducts all worshiping ceremonies and leads the people in sacrificing rites to the ancestral spirits. Thus, she orders, as required by tradition, that Menyani reports the birth of is child to the
Council of elders (Bwalo), kills a goat and give the head and one hind-leg to the Bwalo so that sacrifices can be performed, for "failure to worship the spirits when a child is born presages bad omen" [22].

Furthermore, Naphiri the Namkungwi is said to be the village priest and soothsayer, "she [is] the sole link between the villagers and the mysterious world of the dead. Her prophecies and ministration form an important part of [the villagers'] belief in Mulungu, God, the Upright One, and His numerous manifestations" [22]. In one instance, when a strong whirlwind swept through the village causing panic, Headman Banda could not let the village perish at the hands of Thunga (the sacred serpent). Thus, he went to see Naphiri the Namkungwi for assistance: "Mama Naphiri, what brings me, and the elders, to you is the disaster. [...] we do not know why we should be visited by the whirlwind. [...] what have we done to deserve this suffering?" [22]. In response the soothsayer said:

This is a retribution, [...] people of this village had forgotten the spirits. Thunga is hangry with all of you. [...] Your son Menyani is responsible for the disaster. Menyani has done evil to the village. Many seasons have gone by since his wife had a male child. We did not worship the spirits![22].

Subsequently, she requested that neither flour nor beer was need in order to appease the spirits. Thunga will but only accept meat: "only meat will save us" [22]. By implication, only Menyani's flesh will be accepted by the spirits: "Thunga wants Menyani's blood [...]. All meat is not meat; Thunga wants special meat, Menyani's flesh" [22] she says. After a heated debate a compromise was reached, Headman Banda offered, on behalf of his son Menyani, a fat cow, which Naphiri accepted: "Yes, a fat cow! All is well now. [The] spirits tell me that Thunga will accept" [22] she says.

The roles played by a medicine man/woman cannot be overemphasized. According to John Mbiti [23], the medicinemen and women, also known as "herbalists" or "traditional doctors", are the greatest gift to African societies. Although European-American wrongly call them "which-doctors" - a term that Mbiti says "should be buried and forgotten forever" - these specialists are useful to the community. Elaborating on the roles of medicine-men/women, Mbiti [23] further states:

First and foremost, medicine-men/women are concerned with sickness, disease and misfortune [...] the medicine$\mathrm{man} /$ woman is in effect both doctor and pastor to the sick person. His/her medicines are made from plants, herbs, powders, bones, seeds, roots, juices, leaves, liquids, minerals, charcoal and the like, and in dealing with the patient, s/he may apply massages, needles or thorns, and he may bleed the patient; he may jump over the patient, $\mathrm{s} /$ he may use incantations and ventriloquism, and s/he may ask the patient to perform various things like sacrificing a chicken or goat, observing some taboos or avoiding certain foods and persons - all these in addition to giving the patient physical medicines.

Considering the important roles played by medicine- 
men/women in African societies, it not surprising that, when Tinenenji accidentally burned her foot with hot porridge erupting from a pot, Naphiri, the village midwife and medicine-woman was called in to perform the healing rites and apply traditional medicine on Tinenenji's foot. The irony of the situation is that, Tinenenji's burn which appeared benign slowly developed into a sore as the medicine and healing rites could not help but only worsened the sore.

Contact with the Western world, especially through the experience of colonisation, brought with it the introduction of western medicine, education and tax system. Thus, the reader learns that, while Tinenenji was nursing her wound, a white missionary who was in search of sick persons examined Tinenenji's wound and suggested she should "go to Bamoto mission hospital for free treatment" [22]. But, suspicious of the white man's medicine, the villagers argued that, if Tinenenji went to the mission hospital for treatment, she would never get better; they believed that despite Naphiri's medicine, "the sore refused to heal [...] because it was not an ordinary ulcer. It must have been caused by Thunga because
Menyani had not fulfilled his duties at the Bwalo" [22].

It should be notes that, although Tinenenji eventually goes the mission hospital for treatment, as soon as she start getting better, she decides to return to the village; she believes that, once her husband pays Naphiri what was due to her as required by tradition, the latter will invocate Thunga the sacred serpent and she will be cured. This belief corroborates John Mbiti's [23] view that,

In African villages, disease and misfortune are religious experiences [...] Obviously some of the activities involved in dealing with illness may not have any overt value, but they are psychologically vital and no doubt play a great role in healing the sick or helping the sufferer. In this case, the means are less important than the end, and that is how both the medicine-man and his patient see and experience the situation which brings them together.

This explains why Tinenenji leaves the mission hospital with her wound not completely cured. She believes that only Naphiri traditional healing power can save her. Contrary to her belief, Tinenenji's wound worsens and she eventually dies.

Table 3. Names in Before Dawn.

\begin{tabular}{|c|c|c|}
\hline Characters Name & Meaning & Role \\
\hline $\begin{array}{l}\text { Kavumba (circumstantial name). His } \\
\text { birth occurred at the same time as a } \\
\text { heavy thunderstorm. }\end{array}$ & $\begin{array}{l}\text { Whrilwind. The name also has a religious } \\
\text { significance; it represents the sacred } \\
\text { serpent (Thunga), the spirit that brings life } \\
\text { and death to the village. This spirit often } \\
\text { appears in the form of whirlwind that } \\
\text { visits the villages and its people. }\end{array}$ & $\begin{array}{l}\text { The protagonist. Son of Tinenenji and Menyani. } \\
\text { After spinning around the city in search of a job, Kavumba returns } \\
\text { to his homestead, like Thunga the sacred serpent who returns to his } \\
\text { abode in the sourounding mountains after visiting the villages. }\end{array}$ \\
\hline Tinenenji (proverbial name) & What can we say. & $\begin{array}{l}\text { Kavumba's mother. She convincingly believes in traditional ways } \\
\text { of life and medicine. Despite the availability of European, } \\
\text { medicine, she resorts to traditional healing for her wound. } \\
\text { Ironically, the wound degenerates into an incurable ulcer that } \\
\text { eventually takes her life. }\end{array}$ \\
\hline Menyani & $\begin{array}{l}\text { Derives from the verb menya- "to beat"; } \\
\text { beat them. This name also signifies a baby } \\
\text { who is expected to beat in diligence, } \\
\text { hardwork, leadership, competitive } \\
\text { activities. }\end{array}$ & $\begin{array}{l}\text { Kavumba's father. His father, Headman Banda, expected Menyani } \\
\text { to excel in leadership and eventually inherit his throne. Ironically, } \\
\text { Menyani difies tradition. He does not visit the village Council } \\
\text { (Bwalo) to listern to elders and learn leadership skills. Instead, he } \\
\text { excels in beating up anyone who opposes his views. His } \\
\text { intransigence leads to his alienation from the villagers, much to } \\
\text { Headman Banda's disappointment. }\end{array}$ \\
\hline $\begin{array}{l}\text { Thandiwe (Proverbial name). The } \\
\text { name belongs to Mulambe clan }\end{array}$ & Beloved & $\begin{array}{l}\text { Young woman whose beauty is admired by every man in the } \\
\text { village. }\end{array}$ \\
\hline Dingani (Proverbial name) & $\begin{array}{l}\text { "To be alone" i.e. a baby whose parents } \\
\text { are expressing the sentiment that too many } \\
\text { elders in the family have died. }\end{array}$ & $\begin{array}{l}\text { The man who brings the news from Menyani who left his village } \\
\text { incognito, after the villagers alienated him due to his fighting } \\
\text { behaviour }\end{array}$ \\
\hline $\begin{array}{l}\text { Ganizo (Proverbial name), derives } \\
\text { from the verb ganiza - "to think" }\end{array}$ & Thought & $\begin{array}{l}\text { The keeper of Bwalo (men's court or elders Council). His main } \\
\text { role is to ensure that villagers obey traditions and adhered to them. } \\
\text { In a nutshel, he is the 'hears and eyes' of Banda, the village } \\
\text { Headman Banda. }\end{array}$ \\
\hline $\begin{array}{l}\text { Namkungwi. Her real name is } \\
\text { Naphiri. Namkungwi is a title name } \\
\text { given to Naphiri because of her } \\
\text { profession. }\end{array}$ & Midwife & $\begin{array}{l}\text { Besides her midwifery role, Naphiri, the Namkungwi, is also the } \\
\text { village medicine woman and priestess. She conducts all } \\
\text { worshiping ceremonies and leads the people in sacrificing rites to } \\
\text { the ancestral spirits. }\end{array}$ \\
\hline
\end{tabular}

\section{Conclusion}

This paper is a literary anthropomastics appraisal of personal names of characters in three Zambian novels namely Bitterness, A cowrie of Hope and Before Dawn by Malama Katulwende, Binwell Sinyangwe and Andrea
Masiye, respectively. These novels are set among the communities that include the Bemba, Mambwe/Namwanga, and Chewa.

The analysis reveals the sociocultural factors which influence the choice of names in these different settings. The study also underscores the use of personal names in literary texts to achieve stylistic effects. It is realised that the Bemba, 
Mambwe/Namwanga, and Chewa communities give names that reflect the association clan, ancestral spirits, traditional beliefs and wishes for the child, human qualities, sociocultural and circumstantial names to their children for numerous reasons. This finding confirms the assertions by scholars mentioned earlier that, names are more than mere linguistic labels used to reflect issues of identity, life experience and belief system of a group of people.

The other significant finding from this analysis is that writers of these texts used characters whose names indicate the themes of the texts. In Bitterness, Besa Musunga is expected to keep his ancestral shrine and tradition as well as the entire tribe. Ironically, he fails to live to that expectation. Hence, Musunga Fyonse bitterly curses his son. In A Cowrie of Hope, Nasula (mother of Sula) does not 'let things be' like her daughter. Instead she, as her nickname reveals, could not let Gode, the robber of her bag of beans get away with her crime; she makes sure that he is arrested and pays for his crime. Lastly, in Before Dawn, Kavumba (the whirlwind), after several failed attempts to find work in the city, decides to return to his homestead, thus reminiscing Thunga the sacred serpent that returns to its abode in the mountains, after visiting the villages. As for Menyani, he disappoints his father, who expected him to beat or excel in leadership qualities. And Naphiri, the Namkungwi (the village priest and soothsayer) symbolises keeper the tradition and cultural practices overseer and ensures that people of Banda village uphold cultural traditions of their ancestors without fail.

My study further reveals that the works examined foreground the onomastic implication of the characters' names or nominal labels in the respective narrative contexts as well as the writers' point of view, ideological stance or world view. Indeed, as Achebe (cited in Ngugi [30]) rightly points out, African novelists are teachers who ought to educate or inform - the Western world particularly - about social matters in their African society and its rich cultural traditions, beliefs, and philosophy. This study has also proven that names in literary texts are symbolic indicators of themes and also contribute to the interpretation of a text.

\section{References}

[1] Achebe, C. (1958). Things Fall Apart. London: Heinemann.

[2] Adamic, L. (1942). What's Your Name? New York: Harper \& Brothers.

[3] Adjah, Olive A. (2011). What is in a Name? Ghanaian Personal Names as Information Sources. African Research \& Documentation, (117): 3-17.

[4] Agyekum, K. (2006). The sociolinguistic of Akan personal names. Nordic Journal of African Studies, 15 (2): 206-235.

[5] Allagbé, Ayodele A. (2016). Character Naming and Authorial Attitudes in Contemporary African Literature." Research on Humanities and Social Sciences, 6, (4): 20-28.

[6] Alvarez-Altman, Grace. (1981). Literary Onomastic
Typology: Analytic Guidelines to Literary Onomastics Studies." Literary Onomastics Studies, (8): 220-230.

[7] Al Zumor, A. W. Q. G. (2009). A Socio-cultural and Linguistic Analysis of Yemeni Arabic Personal Names. GEMA Online Journal of Language Studies, 2, 15-25.

[8] Blum, S. D. (1997). Naming practices and the power of Words in China. Language in Society, (26): 357-379.

[9] Butler, J. O. (2010). The power \& politics of naming: Literary Onomastics within Dystopian Fiction (Unpublished M. Phil. thesis). University of Glasgow, Scotland.

[10] Chauke, M. T. (2015). Personal names and Naming Practices among the Vatsonga. Anthropologist, 19 (1): 303-312.

[11] Croft, J. B. (2009). Naming the evil one: Onomastic strategies in Tolkien and Rowling. Mythlore, (28). 149-163.

[12] Ennin, T. P. and Nkansah, N. B. (2016). A Literary Anthropomastics of Three Selected African Novels: A Cross Cultural Perspective. International Journal of Society, Culture \& Language, 4 (1): 70-79.

[13] Fasiku, G. (2006). Yoruba proverbs, names and national consciousness. The Journal of Pan African Studies, vol. 1, (4).

[14] Finnegan, R. (2012). Oral Literature in Africa. New York: Oxford University Press.

[15] Gerba, T. G. (2014). Morphosemantic Analysis of Oromo Personal Names. International Journal of Innovative Research \& Development, 3, (13): 252-259.

[16] González, V. T. (2010). Approche onomastique de les grandes marées de Jacques Poulin. Cedille, Revista de Studios Francesses, (6): 245-256.

[17] Guma, M. (2001). The Cultural Meaning of Names among Basotho of Southern Africa: A Historical and Linguistic Analysis. Nordic Journal of African Studies, 10 (3): 265-279.

[18] Katakami, H. (1997). Personal Names and Modes of Address among the Mbeere. African Study Monograph, 18 (3, 4): 203-212.

[19] Katulwende, M. (2005). Bitterness. New York: Mondial. [

[20] King, Debra W. (1998). Deep Talk: Reading African-American Literary Names. Charlottesville: University Press of Virginia.

[21] Mashiri, P. (1999). Terms of Address in Shona: A Sociolinguistic Approach." Zambezia 26, (1): 93-110.

[22] Masiye, A. S. Before Dawn. (1970) Lusaka: Zambia Educational Publishing House.

[23] Mbiti, John S. (1970). African Religions and Philosophy. New York: Anchor Books.

[24] Mensah, E. and Imeobong Offong. (2013). The Structure of Ibibio Death Prevention Names. Anthropological Notebooks, 19 (3): 41-59.

[25] Mutunda, S. (2011). Personal Names in Lunda Cultural Milieu. International Journal of Innovative Interdisciplinary Research, (1): 14-22.

[26] Mutunda, S. (2015). Descriptions of Masculinity in African Women's Creative Writing: Mariama Ba, Philomène, Bassek, Delphine Zanga Tsogo, Calixthe Beyala, Aminata Sow Fall. New York: The Edwin Mellen Press. 
[27] Mutunda, S. (2016). Luvale Personal Names and Naming Practices: A socio-Cultural Analysis. International Journal of Education, Culture and Society, 1 (3): 74-81.

[28] Neethling, B. (2004). Name Choice among the Xhosa of South Africa. The Language Quarterly, xxix (4), 4-6.

[29] Ngonyani, Deo. (2001). Onomastic Devices in Shaaban Robert's Narratives. Journal of African Cultural Studies. 14 (2): 125-136.

[30] Ngugi, WA Thiongo. (1986). Decolonizing the Mind: The Politics of Language in African Literature. Oxford: James Currey.

[31] Obeng, S. G. (1998). Akan death prevention names: A pragmatic and structural analysis. Names, 46 (3): 163-187.

[32] Ogie, O. (2002). Personal Names and World View. In Ohioma I. Pogosan and Francis O. Egbokhare. (Eds.), New Perspectives in Edoid Studies: Essays in Honour of Ronald Peter Schaefer. Cape Town, RSA: Centre for Advanced Studies of African Society, Book Series No. 20.

[33] Oha, O. (2009). Praise names and power de-construction in contemporary Igbo Chiefship. Culture, Language and Representation, (7): 101-116.

[34] Olatunji, A. et al. (2015). Personal Name as a Reality of
Everyday Life: Naming Dynamics in Select African Societies. The Journal of Pan African Studies, 8 (3): 72-90.

[35] Omari, C. K. (1970). Personal Names in Socio-cultural Context. KiSwahili, Vol. 40.

[36] Oxford Advanced Learner's Dictionary. 2010. Oxford: Oxford University Press.

[37] Penda, Chanda. (2013). Encyclopaedia of Zambian Names. Lusaka: Pensulo Publishers Ltd.

[38] Sinyangwe, Binwell. (2000). A Cowrie of Hope. Oxford: Heinemann.

[39] Suzman, S. M. (1994). Names as Pointers: Zulu Personal Naming Practices. Language in Society, 23 (2): 253-272.

[40] Udoye, I., \& Cyril, O. (2011). A morphological analysis of Akwa personal names. Journal of Arts and Contemporary Society, (3): 85-89.

[41] Wamitila, K. W. (1999). What's in a name: Towards Literary Onomastics in Kiswahili Literature. AAP, 60, 35-44.

[42] Wanich, Melody. edition.cnn.com/2008/HEALTH/family. Retrieved on $21^{\text {st }}$ March, 2017.

[43] Zawawi, S. M. (1998). African Muslim Names: Images and Identities. Trenton, NJ: Africa World Press, Inc. 